\title{
Development of Preventive Vaccines for Hepatitis C Virus E1/E2 Protein
}

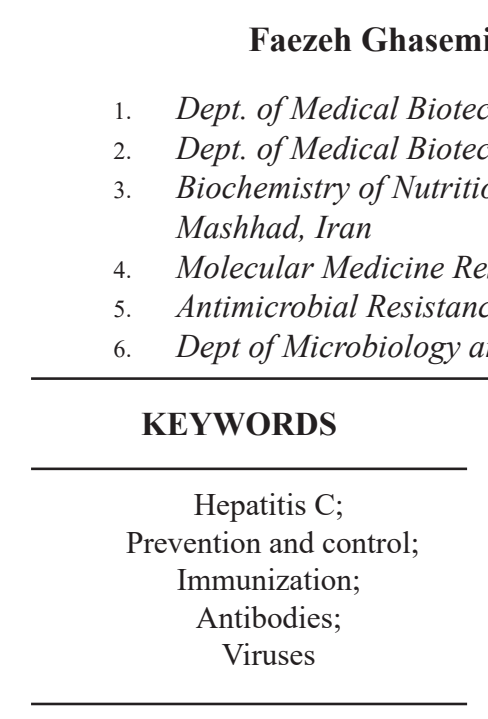

Article Info

Received 14 Feb 2017;

Accepted 03 July 2018;

Published Online 17 July 2018;
ABSTRACT

Hepatitis $\mathrm{C}$ virus (HCV) is responsible for a vast majority of liver failure cases. HCV is a kind of blood disease estimated to chronically infect $3 \%$ of the worlds population , causing significant morbidity and mortality. Therefore, a complete knowledge of humoral responses against HCV, resulting antibodies, and virus-receptor and virus-antibody interactions, are essential to design a vaccine. HCV epitopes or full sequence of $\mathrm{HCV}$ proteins can induce HCV specific immune responses. In fact, structural proteins are usually the main target of humoral responses and non-structural proteins are usually the main target of cellular responses. Hence, various vaccines based on distinct antigenic combinations are developed to prevent HCV infection and the current study tried to summarize them.

Corresponding information:

Zahra Meshkat, Antimicrobial Resistance Research Center, Mashhad University of Medical Sciences,

Mashhad, Iran. E-mail: meshkatz@mums.ac.ir

Copyright (C) 2018, IRANIAN JOURNAL OF PATHOLOGY. This is an open-access article distributed under the terms of the Creative Commons Attribution-noncommercial 4.0 International License which permits copy and redistribute the material just in noncommercial usages, provided the original work is properly cited.

\section{Introduction}

Hepatitis $\mathrm{C}$ virus (HCV) is an enveloped, single stranded RNA virus belonging to Flaviviridae family and hepacivirus genus $(1,2)$. It is estimated that $3 \%$ of the world's population have HCV infection. Approximately, $75 \%$ of acute $\mathrm{HCV}$ infections develop to chronic HCV out of which 3\%-11\% cause liver cirrhosis, liver failure, and hepatocellular carcinoma (HCC) (3-6). Although HCV was discovered in 1988, an effective vaccine is not available yet. Therefore, several studies sought to produce an effective vaccine against $\mathrm{HCV}$ infection. Facts that hamper the vaccine production include lack of an appropriate disease host model, moderate titer of produced antibodies against the envelope glycoproteins and their short half-life, and inability to produce high amounts of virus in tissue culture (7).

Despite extensive research, an effective vaccine is not available yet. A vaccine should be able to stimu- late neutralizing antibodies in order to be efficient. Recent treatment of HCV used directly acting antiviral agents (DAAs), but there is an important demand to study the new vaccine to prevent infection. It is reported that annual health care costs of patients with mild chronic HCV infection, HCC, and cirrhosis are about $€ 2,756, € 11,437$, and $€ 6,258$, respectively (7).

Furthermore, other obstacles are also on the way of HCV vaccine development. For instance, different HCVs with distinct divergent sequences in specific regions of the genome are identified that suggest various mutations in viral genome during the infection. Mutations especially involve the N-terminal region of E2 glycoprotein; i e, hypervariable region 1 (HVR1) and this region has the highest variability amongst the known isolates (8). This genetic heterogenicity helps the virus escape host's immune system. HCV treatment conventionally depends on interferon alpha (INF- $\alpha$ ) and ribavirin associated with adverse side 
effects. Recently, a new class of drugs, called direct acting antivirals (DAA), were developed to be used in combination with INF- $\alpha$ and ribavirin in order to increase their effectiveness, however, the setbacks are high cost and increased side effects (9). Keeping in mind the high expenses and side effects of the current treatments of hepatitis $\mathrm{C}$ and considering the fact that only a small percent of patients can be completely cured (10), an effective HCV vaccine is apparently needed.

Developments are made in the field of producing model systems to study the virus-receptor and virusantibody interactions. Although the exact relationship between HCV and neutralizing antibodies is unknown, these model systems improved the knowledge about the nature of antibodies responding against $\mathrm{HCV}$ and the complexity of host-virus relationships.

Infection with $\mathrm{HCV}$ induces weak immune response, thus $75 \%$ to $85 \%$ of infected population develop chronic infections (11); however, $20 \%$ of infected individuals can resolve the infection by their natural immune responses. Thus, an effective vaccine can be achieved. Moreover, considering the high cost of $\mathrm{HCV}$ treatment and its deteriorating effect on human health, producing a beneficial $\mathrm{HCV}$ vaccine seems to be a logical answer.

$\mathrm{HCV}$ epitopes or full sequence of $\mathrm{HCV}$ proteins can induce HCV specific immune responses. In fact, structural proteins are the main target of humoral responses and non-structural proteins are the main target of cellular responses. Hence, various vaccines, based on distinct antigenic combinations, are developed to prevent $\mathrm{HCV}$ infection that the current study tried to summarize them.

\section{Effects of neutralizing antibodies on chronic $\mathrm{HCV}$ infection}

Immunization against $\mathrm{HCV}$ should stimulate the production of neutralizing antibodies and its efficacy is assessed based on the amount of neutralizing antibodies it produces (12). Analysis of structural sequences in chronic infection indicated that neutralizing antibody response is correlated with the sequence evolution and is likely the result of immune escape
(13). In 2012 Raghuraman et al., evaluated the neutralizing antibody and cellular immunity responses in a patient with chronic hepatitis $\mathrm{C}$ and cleared the infection after 62 weeks. Viral clearance was associated with neutralizing antibody emergence in the week 48 of infection (14).

Neutralizing antibodies play important roles in patients with former HCV infection that cleared the virus and are infected again. A study was conducted on injecting drug abusers infected with HCV that were able to clear the virus. These subjects were infected again with $\mathrm{HCV}$ and $83 \%$ of them were able to clear the infection again, considering that $25 \%$ of individuals infected with HCV cannot clear the virus. Moreover, the duration and viremia were significantly lower in reinfected subjects (15).

These results suggest that neutralizing antibody production in the initial phase of infection is correlated with viral clearance rate. Passive delivery of neutralizing antibody to model animals protects them from viral infection. In the study by Morin et al., $250 \mathrm{mg} /$ $\mathrm{kg}$ of HCV1 human monoclonal antibodies, which identify a linear and conserved epitope in E2 glycoprotein, was administered to chimpanzees 30 minutes after injecting HCV genotype 1aH77. The animals that received $250 \mathrm{mg} / \mathrm{kg}$ were completely protected against the infection whereas the ones that received $50 \mathrm{mg} / \mathrm{kg}$ were susceptible to infection. Infection was reduced to an undetectable level after administration of $250 \mathrm{mg} / \mathrm{kg}$ of HCV1 antibodies to a chimpanzee 42 days after infection; however, infection rate increased again after 14 days. These viruses had N415D mutation in E2 glycoprotein that granted them immunity to HCV1 antibodies; three other chimpanzees with chronic HCV infection were administered with 40 $\mathrm{mg} / \mathrm{kg}$ of HCV1 antibodies, viral load was reduced to an undetectable level for 21 days in one of them, but after that viruses with N417S1 mutation emerged again. The other two chimpanzees did not show virus return. Therefore, application of sterilizing doses of antibodies before infection is preventing, though they are not protective after getting infected and are only able to reduce the viral load (16). 


\section{E1 and E2 glycoproteins}

The envelope proteins are located on the surface of the virion and are the major viral antigens that evoke protective immune responses. E1 and E2 are two envelope proteins of HCV. The E1 glycoprotein contains 192 amino acids ranging from position 192 in the polyprotein to 38 , while E2 glycoprotein is a 363-amino-acid-long protein ranging from position 384 to 746 in the polyprotein (17).

Recently, the crystal structure of the core of E2 ectodomain was determined $(18,19)$. Unlike previous considerations (20), E2 glycoprotein does not represent the structure shared by class II viral fusion proteins, but rather it has a globular structure with many regions without any regular secondary structure (18, 19). These new findings suggest that $\mathrm{E} 1$ alone or in association with E2 may be responsible for the fusion step, since E2 lacks the structural hallmarks of fusion proteins $(18,19,21,22)$. However, this hypothesis is not proven yet, because the structural data concerning the E1 ectodomain are inadequate.

E1 and E2 interact with each other to form a noncovalent heterodimer; finally, disulfide bonds stabilize E1 and E2 to appear as large covalent complexes on the surface of the virion (23). Moreover, the Nlinked glycosylation of the E1 and E2 is also essential to form these multi-subunit complexes that facilitate the entry of the virus into host cells (23-25).

RNA-dependent RNA polymerase of HCV lacks the repair activity; therefore, HCV genome shows extensive intergenotypic and intragenotypic variabilities (26). The genes encoding E1 and E2 glycoproteins display the highest degree of genetic heterogeneity, and hypervariable region 1 (HVR1) of E2 is the most variable of all regions of the HCV genome $(27,28)$. Cheng et al., showed that E1 and E2 of HCV subtype $1 \mathrm{~b}$ that is the most variable among different subtypes, and E1 is more variable than E2 in subtype 1b. Furthermore, they found more N-glycosylation sites in E2 than E1 in all subtypes. E1 of subtype $1 \mathrm{~b}$ had the most $\mathrm{N}$-glycosylation sites compared with other E1 proteins (29). N-glycosylation plays an important role in the folding and immunogenicity of HCV gly- coproteins (41). The glycan shield masks neutralizing epitopes on the virion surface reducing the immunogenicity of the envelope proteins (38). According to Cheng's study, E1 glycoprotein may play an important role in provoking neutralizing antibodies and should be further studied, however, few neutralizing antibodies are identified against E1 glycoprotein, which indicate its low immunogenicity (30).

A physical interaction between E1-E2 heterodimer and host cell surface receptors is needed for the entry of viruses into cells. Glycosaminoglycans and lowdensity lipoproteins (LDLs) are thought to be vital for initial attachment of the virion and the host cell (31). Additionally, four other receptors to function in viral entry include CD81 (32), occludin (33), scavenger receptor class B type 1 (SR-BI) (34), and claudin-1 (35).

\section{Antibodies that target E1}

Neutralizing antibodies that target E1 are few since E1 is covered by E2 in the E1-E2 heterodimer. In a study on H-111 antibody against E1 glycoprotein, it was observed that this ab is exclusive for YEVRNVSGVYH sequence near the N-terminal of E1 and forms immune complex with E1E2. Notably, this antibody is capable of connecting to E1 of genotypes 1a, 2b, and 3a, which suggests the fact that $\mathrm{H}-111$ epitope is hugely conserved. An effective vaccine should include epitopes that are conserved between various genotypes; therefore, the vaccine can prevent cell binding and entry of the virus. Therefore, ---RN-SG$\mathrm{Y}$ sequence is a suitable candidate for the development of $\mathrm{HCV}$ vaccine (36).

Meunier et al., evaluated the human monoclonal antibodies against E1 glycoprotein that had the potential to control HCV infection. IGH526 and IGH505 were recognized as antibodies that could identify different, but overlapping epitopes. These antibodies strongly neutralized HCVpp covered by genotype 1a, 1b, 4a, $5 \mathrm{a}$, and 6a glycoproteins and to lesser extent genotype 2a glycoproteins; however, they had no effect on genotype 3 a glycoproteins. Topography of epitopes of the two antibodies revealed a region between amino acids 313 and 327 of E1 glycoprotein (30). 
In 2011, Kachko et al., assessed the profile of antibodies induced by immunization of mice and chimpanzees with recombinant E1-E2 glycoproteins. In their study, the quality of antibodies was evaluated using peptide scan technique and in vitro neutralization test for three different HCV subtypes including 1a, 2a, and 1b. Interestingly, the results suggested that epitopes with most immunogenicity induced antibodies that had the least neutralizing capacity. Moreover, three important regions for neutralization were confirmed in this study including a region with high conservation of $85 \%$ to $95 \%$ and a potential of cross-neutralization. Therefore, it was suggested that deletion of some immunogen regions from the coating glycoproteins results in the production of more efficient neutralizing antibodies (37).

Grollo et al., used human serum containing antiHCV IgG to isolate E1 and E2 epitopes of HCV genotype 1aH77. Bound epitopes were identified using mass spectroscopy; three different antigenic regions in E1E2 glycoprotein were specified using anti-HCV IgGs. At least four of these epitopes were conserved in three HCV genotypes and bound to serum antibodies found in patients with chronic HCV or the ones in convalescence period. Synthetic vaccines based on these epitopes trapped virions in patients with viremia, they also prevented entry of HCVpp to Huh7 cells (38).

\section{Antibodies that target E2}

In 1995, Zibert et al., introduced the hypothesis that neutralizing antibodies target HVR1 region of E2 glycoprotein. To test their hypothesis they used serum of patients infected with HCV and concluded that HVR1 N-terminal was immunodominant in natural infections (39).

Immune serums produced against HVR1 sequence were capable of protecting chimpanzees against the same strain of virus. These antibodies were specialized for each genotype and had limited ability to neutralize variants that escaped immune system by mutations in HVR1 region (40).

In 1998, Lechner et al., sought to identify the E1 and E2 regions responsible for the production of neu- tralizing antibodies. They transcribed $\mathrm{pE} 1$ and $\Delta \mathrm{pE} 2$ proteins that included amino acids 174 to 337 of E1 and 411 to 688 of E2 glycoproteins of HCV-AD78 isolate, respectively. The $\Delta \mathrm{pE} 2$ protein lacked the HVR1 region. The $\mathrm{pG}-\mathrm{HVR} 1$ protein that represented the amino acids 384 to 410 of HVR1 region of HCVAD78 isolate was used as the control. These three proteins were tested by an immunoprecipitation assay in order to identify antibodies in the sera of individuals infected with HCV-AD78. The sera were obtained four to eight months after the infection and patients either cleared the infection or developed chronic liver disease. Results showed that both groups had a high level of anti-pE1 and -pE2 antibodies. Therefore, this part of envelope proteins constitutes B-cell epitopes. Interestingly, antibody response against $\mathrm{pE} 1$ and $\triangle \mathrm{pE} 2$ was not significantly different between the two groups; however, anti-pGHVR1 antibody correlated with infection clearance. Rabbit antibodies against $\mathrm{pE} 1$ and $\triangle \mathrm{pE} 2$ were used to assess the ability of HCV binding to susceptible cells in tissue culture. Results indicated that despite the production of antibodies against epitopes outside HVR1, these antibodies were not capable of viral clearance (41).

Most neutralizing identified antibodies target the entry domain of CD81; HCV also evolved various ways to cover this region of E2. E2 glycoprotein has $11 \mathrm{~N}-$ glycosylation domains and these domains participate in HCV folding and entry (42). It seems that these regions limit immunogenicity of E2 and prevent action of neutralizing antibodies, similar to gp120 in HIV $(43,44)$.

In 2010, Francois Helle et al., concluded that glycosylation domains in E1 had no part in hiding potential epitopes of this protein. However, at least three glycans in E2, named EN11, EN5, and EN1 support binding of HCVpp to neutralizing antibodies and create an immune escape mechanism for the virus (45). It seems that antibodies act as a stimulus for escaping the immune system (46).

Studying the serologic responses to synthetic oligonucleotides derived from HVR1 showed several serologic cross-reactions to non-HVR1 peptides. 
Variability of HVR1 sequence was significantly correlated with severity of humeral response cross-reaction. Thus, HVR1 is stimulated by the host's immune response (47). HCV sequence evolution analysis in infected individuals showed that in the absence of neutralizing antibodies HVR1 sequence remains constant, although as soon as the production of neutralizing antibodies begins, HVR1 sequence starts evolving (13).

Analysis of the responses to HVR1-specific antibodies in patients infected with HCV suggested that individuals that cleared the infection rapidly, had detectable anti-HVR1 antibodies in their serum in the first six months of their infection (48). Therefore, anti-HVR1 antibodies help the viral clearance under some circumstances.

Although anti-HVR1 antibodies act primarily on a specific genotype, evidence suggests that anti-HVR1 antibodies that have reactivity with a wide spectrum of non-related HVR1s can be produced. In 1999, Shang et al., successfully created antibodies capable of reacting with 16 out of 17 non-related sequences of HVR1. In their study rabbits were immunized with a series of synthetic HVR1 peptides, and then the produced anti-HVR1 antibodies were purified. These antibodies were capable of trapping HCV in the plasma of 22 out of 23 patients; moreover, they prevented the binding of HCV to MOL14 cells (49).

As mentioned before, CD81-binding domain in E2

Table 1. Residues Involved in CD81 Binding

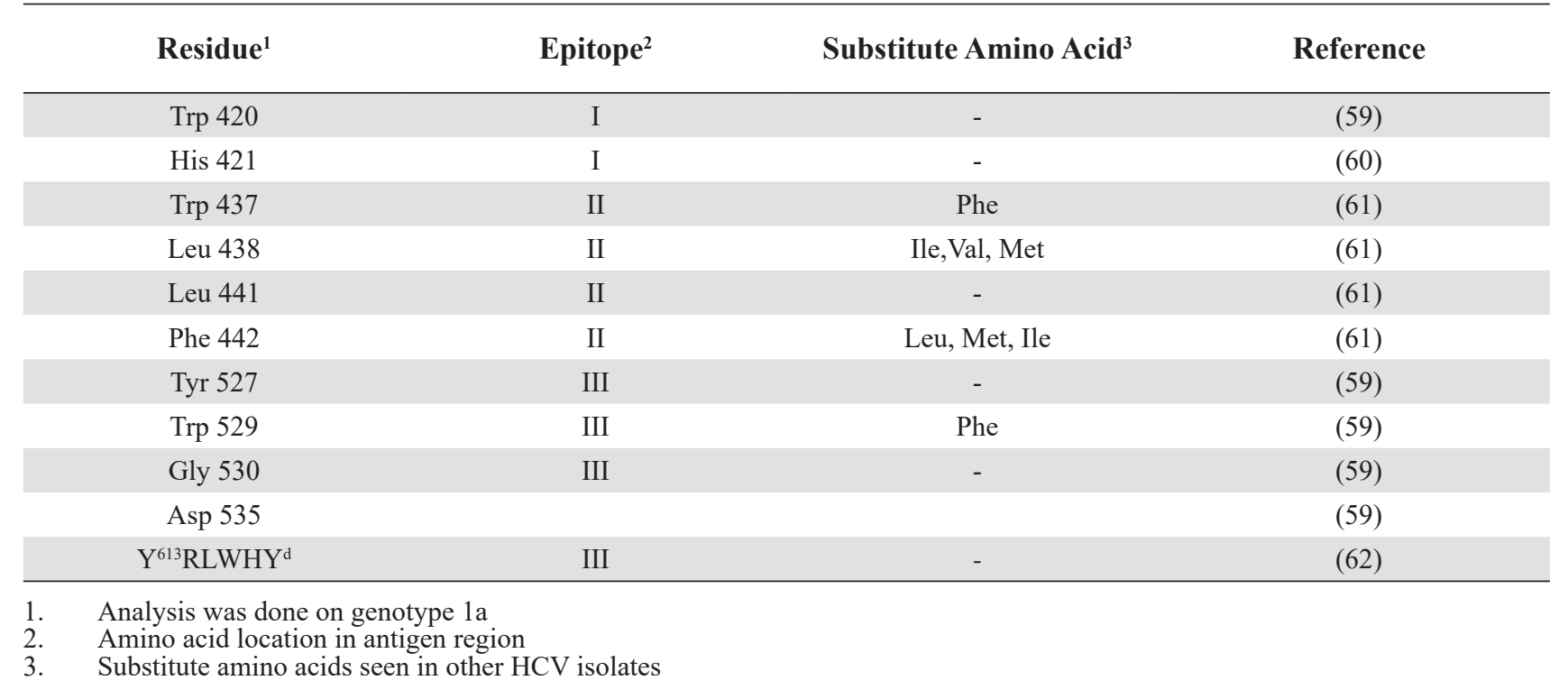

glycoprotein is a target of neutralizing antibodies. This sequence is on the surface of E2 and antibodies against it are highly preserved, thus have crossneutralizing abilities (50-52).

Residuals involved in binding to CD81 were identified using targeted mutagenesis in this motif. Studies that investigated mapping of the residuals and their results are summarized in Table 1.

An astonishing feature was that most of these residues were aromatic and hydrophobic and strictly conserved between genotypes. For example, in the case of Trp437, phenyl alanine was the dominant amino acid. Several neutralizing antibodies against E2 block the binging of CD81 and have amino acids that pass through 411 to 428,429 to 448 , and 523 to 549 regions; therefore, they overlap in the area involved in the binding of CD81.

A portion of antibodies targeting $\mathrm{E} 2$ can bind to their epitopes in synthetic sequences that are the analogues of residues 411 to 428 (epitope 1) and 429 to 448 (epitope 2). Antibodies that bind to the epitope inside 523 to 549 residue (epitope 3 ) include 1:7 and A8; however, these antibodies are conformation-dependent (50, $53,54)$. Another portion of antibodies identify detached epitopes and bind to E2 only when it is folded. These antibodies include CDH5, CBH7, and AR3A. Antibodies against E1 and E2 glycoprotein are summarized in Table 2. 
Table 2. Antibodies Targeting HCV Envelope Glycoproteins; Amino Acids Reported by H77 Subtypes

\begin{tabular}{|c|c|c|c|c|c|}
\hline Antibody & Target Epitope (Amino Acid) & Epitope Type & Target Reaction & $\begin{array}{l}\text { Antibody } \\
\text { Source }\end{array}$ & Reference \\
\hline H-111 & $192-211$ & Linear & Unknown & Human & (52) \\
\hline IGH505 & $312-327(\mathrm{E} 1)$ & Linear & Unknown & Human & (30) \\
\hline IGH526 & $312-327(\mathrm{E} 1)$ & Linear & Unknown & Human & (30) \\
\hline $9 / 27$ & 396-407 (HVR1) & Linear & SR-BI & Rat & (63) \\
\hline $7 / 59$ & 384-391 (HVR1) & Linear & SR-BI & Rat & (63) \\
\hline H77.39 & 415 and 417 & Linear & CD81/SR-B1 & Mouse & (64) \\
\hline $3 / 11$ & $412-423$ & Linear & CD81 & Rat & (65) \\
\hline HCV1 & $412-423$ & Linear & CD81 & Human & (66) \\
\hline $95-2$ & $412-423$ & Linear & CD81 & Human & (66) \\
\hline AP33 & $412-423$ & Linear & CD81 & Mouse & $(67,68)$ \\
\hline $2 / 69 a$ & $436-443$ & Linear & Unknown & Rat & $(63-65)$ \\
\hline $1 / 39$ & $432-443$ & Linear & CD81 & Rat & (65) \\
\hline AP320 & $444-471$ & Linear & Unknown & Mouse & (69) \\
\hline $6 / 41 a$ & $480-492$ & Linear & Unknown & Rat & (65) \\
\hline $11 / 20$ & $436-447$ & Linear & CD81 & Rat & (63) \\
\hline $2 / 64 a$ & $524-531$ & Linear & CD81 & Rat & (63) \\
\hline H53 & $540-550$ & Conformation-dependent & Unknown & Mouse & $(59,70)$ \\
\hline H35 & 523 and 530 & Conformation-dependent & CD81 & Mouse & $(59,70)$ \\
\hline H48 & 530 & Conformation-dependent & CD81 & Mouse & $(59,70)$ \\
\hline Fab e137 & $416,420,529,530$ and 535 & Conformation-dependent & CD81 & Human & (71) \\
\hline Fab e20 & 529,530 and 535 & Conformation-dependent & $\mathrm{CD} 81$ & Human & (71) \\
\hline AR3A & $\begin{array}{c}436,424-447,523,530,535,538 \\
\text { and } 540\end{array}$ & Conformation-dependent & $\mathrm{CD} 81$ & Human & $(51)$ \\
\hline AR3B & $436,424-447,530,535$ and 540 & Conformation-dependent & CD81 & Human & (51) \\
\hline AR3C & $424,530,535,538$ and 540 & Conformation-dependent & CD81 & Human & (51) \\
\hline AR3D & $424,447,436-530$ and 535 & Conformation-dependent & $\mathrm{CD} 81$ & Human & (51) \\
\hline $7: 1$ & $523,529,530$ and 535 & Conformation-dependent & CD81 & Human & $(51,53)$ \\
\hline A8 & $523,529,530$ and 535 & Conformation-dependent & $\mathrm{CD} 81$ & Human & $(51,53)$ \\
\hline L1 & Unknown & Conformation-dependent & Unknown & Human & $(51,53)$ \\
\hline CBH4B & Unknown & Conformation-dependent & Unknown & Human & $(36,72)$ \\
\hline CBH4D & Unknown & Conformation-dependent & Unknown & Human & $(36,72)$ \\
\hline CBH4G & Unknown & Conformation-dependent & Unknown & Human & $(36,72)$ \\
\hline CBH5 & $523,525,530,535$ and 540 & Conformation-dependent & CD81 & Human & $(72,73)$ \\
\hline CBH7 & 540 and 549 & Conformation-dependent & $\mathrm{CD} 81$ & Human & $(72,73)$ \\
\hline ALP98 & $644-651$ & Linear & Unknown & Mouse & $(69,74)$ \\
\hline ALP1 & $647-658$ & Linear & Unknown & Mouse & $(69,74)$ \\
\hline
\end{tabular}

\section{Prospects for $\mathrm{HCV}$ vaccine production}

Several vaccines were designed based on the ability of viral subunits to stimulate host's immune system. The first promising results in this field were obtained by Cho et al., in 1994. They successfully immunized chimpanzees against HCV using the purified E1E2 glycoprotein. In their study seven chimpanzees were injected with purified E1E2 glycoprotein; five of them showed complete resistance against homolog
HCV challenge, whereas two chimpanzees developed the infection; however, the severity of infection was lower compared with that of the control group (55).

Frey et al., evaluated the efficacy of vaccination with E1E2 glycoproteins derived from HCV genotype 1a in 60 healthy volunteers. Vaccine was safe and welltolerated. By the enzyme-linked immunosorbent assay (ELISA) and neutralization tests with vesicular stomatitis virus /HCVpp, measurable amounts of 
E1E2 neutralizing antibodies together with CD4+ cell responses were recorded (56).

Only one of the neutralizing antibody producing vaccines was tested on humans. Chiron Corporation created this recombinant E1/E2 vaccine. In preliminary studies on chimpanzees, vaccine could produce significant number of antibodies against E1 and E2; five chimpanzees were immunized against homologous virus and the antiviral effect was correlated with the level of anti-E2 antibodies (55).

Recombinant E1/E2 vaccine with MF59 adjuvant was tested on 41 healthy volunteers. Initial results showed that 15 individuals had antibodies against 313 to 327 region, 21 against HVR1, 23 against epitope 1, and 13 against epitope 2 (57).

In 2013, Law et al., immunized healthy volunteers with recombinant E1/E2 glycoproteins derived from HCV1a subtype. Cross-neutralization was tested using Huh7.5 cells and HCV cell culture (HCVcc). Vaccination induced neutralizing Abs against heterologous HCV1a. In order to evaluate cross-neutralizing responses, three people were selected based on their capacity to neutralize HCV1a virus. At least one of them exhibited broad cross-neutralizing responses against all HCV genotypes (58).

Results of this study and other similar studies increased the hope to produce a vaccine with the ability to produce broad cross-neutralizing. Moreover, using recombinant E1/E2 glycoproteins opened new horizons for researchers to achieve an effective HCV vaccine. One of the most important problems in the field of $\mathrm{HCV}$ is drug resistance, genotypes and different genotypes, extremely high cost of drugs, HCV carrier population, lack of an animal model for the survey immune response of the vaccine, etc. For these reasons, there is an urgent need to identify a prophylactic $\mathrm{HCV}$ vaccine.

\section{Conclusion}

Results of the current study and other similar studies increased the hope to produce a vaccine with the ability to produce broad cross-neutralizing. Moreover, using recombinant E1/E2 glycoproteins will open new horizons for researchers to achieve an effective $\mathrm{HCV}$ vaccine.

\section{Acknowledgements}

Mashhad University of Medical Science Research Council supported this project. This paper was the subject thesis of Faezeh Ghasemi, Ph.D Candidate in Medical Biotechnology, Department of Medical Biotechnology, School of Medicine, Mashhad University of Medical Sciences, Mashhad, Iran (MUMS: 910530).

\section{Conflicts of interest}

The author declared no conflict of interest.

\section{References}

1. Zignego AL, Macchia D, Monti M, Thiers V, Mazzetti M, Foschi M, et al. Infection of peripheral mononuclear blood cells by hepatitis $\mathrm{C}$ virus. Journal of hepatology. 1992;15(3):382-6. https://doi.org/10.1016/0168-8278(92)90073-X

2. Shakeri MT, Nomani H, Mobarhan MG, Sima HR, Gerayli S, Shahbazi S, et al. The prevalence of hepatitis $\mathrm{C}$ virus in mashhad, iran: a population-based study. Hepatitis monthly. 2013;13(3). https://doi.org/10.5812/hepatmon.7723 PMID:23745128 PMCID:PMC3669679

3. Poynard T, Yuen MF, Ratziu V, Lai CL. Viral hepatitis C. Lancet. 2003;362(9401):2095-100. https://doi.org/10.1016/S0140-6736(03)15109-4

4. Micallef JM, Kaldor JM, Dore GJ. Spontaneous viral clearance following acute hepatitis C infection: a systematic review of longitudinal studies. J Viral Hepat. 2006;13(1):34-41. https://doi.org/10.1111/j.1365-2893.2005.00651.x PMID: 16364080

5. Somi MH, Etemadi J, Ghojazadeh M, Farhang S, Faramarzi M, Foroutan S, et al. Risk factors of HCV seroconversion in hemodialysis patients in tabriz, iran. Hepat Mon. 2014;14(6):e17417. https://doi.org/10.5812/hepatmon.17417

\section{PMID:24976839 PMCID:PMC4071359}

6. Gerayli S, Meshkat Z, Pasdar A, Mozafari PM, Banihashemi E, Khajavi MA, et al. The Association Between Oral Lichen Planus and Hepatitis C Virus Infection; A Report From Northeast of Iran. Jundishapur J Microbiol. 
2015;8(4): e16741. $\quad$ https://doi.org/10.5812/ jim.8(4)2015.16741

7. Liang TJ. Current progress in development of hepatitis $\mathrm{C}$ virus vaccines. Nat Med. 2013;19(7):869-78. $\quad$ https://doi.org/10.1038/ $\underline{\text { nm.3183 }}$ PMID:23836237

8. Kurosaki M, Enomoto N, Marumo F, Sato C. Rapid sequence variation of the hypervariable region of hepatitis $\mathrm{C}$ virus during the course of chronic infection. Hepatology. 1993;18(6):1293-9. https://doi.org/10.1002/ hep.1840180602 PMID: $\underline{8244252}$

9. Messina JP, Humphreys I, Flaxman A, Brown A, Cooke GS, Pybus OG, et al. Global distribution and prevalence of hepatitis $\mathrm{C}$ virus genotypes. Hepatology. 2014. PMID:25069599 PMCID:PMC4303918

10. Feuerstadt P, Bunim AL, Garcia H, Karlitz JJ, Massoumi H, Thosani AJ, et al. Effectiveness of hepatitis $\mathrm{C}$ treatment with pegylated interferon and ribavirin in urban minority patients. Hepatology. 2010;51(4):1137-43. https://doi. org/10.1002/hep.23429 PMID:20049907

11. Ghasemi F, Rostami S, Meshkat Z. Progress in the development of vaccines for hepatitis $\mathrm{C}$ virus infection. World J Gastroenterol. 2015;21(42):11984. $\underline{\text { https://doi. }}$ org/10.3748/wjg.v21.i42.11984 PMID:26576087 PMCID:PMC4641120

12. Lambert P-H, Liu M, Siegrist C-A. Can successful vaccines teach us how to induce efficient protective immune responses? Nat Med. 2005;11:S54-62. https://doi.org/10.1038/nm1216 PMID: 15812491

13. Liu L, Fisher BE, Dowd KA, Astemborski J, Cox AL, Ray SC. Acceleration of hepatitis C virus envelope evolution in humans is consistent with progressive humoral immune selection during the transition from acute to chronic infection. J Virol. 2010;84(10):5067-77. https:// doi.org/10.1128/JVI.02265-09 PMID:20200239 PMCID:PMC2863818

14. Raghuraman S, Park H, Osburn WO, Winkelstein E, Edlin BR, Rehermann B. Spontaneous clearance of chronic hepatitis $\mathrm{C}$ virus infection is associated with appearance of neutral- izing antibodies and reversal of T-cell exhaustion. J Infect Dis. 2012;205(5):763-71. https:// doi.org/10.1093/infdis/jir835 PMID:22293431 PMCID:PMC3274373

15. Osburn WO, Fisher BE, Dowd KA, Urban G, Liu L, Ray SC, et al. Spontaneous control of primary hepatitis $\mathrm{C}$ virus infection and immunity against persistent reinfection. Gastroenterology. 2010;138(1):315-24. https://doi. org/10.1053/j.gastro.2009.09.017 PMID: 19782080 PMCID:PMC2889495

16. Morin TJ, Broering TJ, Leav BA, Blair BM, Rowley KJ, Boucher EN, et al. Human monoclonal antibody HCV1 effectively prevents and treats $\mathrm{HCV}$ infection in chimpanzees. PLoS pathogens. 2012;8(8):e1002895. https://doi. org/10.1371/journal.ppat.1002895 PMID:22952447 PMCID:PMC3431327

17. UniProt Consortium. Reorganizing the protein space at the Universal Protein Resource (UniProt). Nucleic Acids Res. 2011;40(D1):D71-5 https://doi.org/10.1093/nar/gkr981

18. Khan AG, Whidby J, Miller MT, Scarborough H, Zatorski AV, Cygan A, et al. Structure of the core ectodomain of the hepatitis $\mathrm{C}$ virus envelope glycoprotein 2. Nature. 2014;509(7500):381-4. https://doi.org/10.1038/ nature13117_PMID:24553139

19. Kong L, Giang E, Nieusma T, Kadam RU, Cogburn KE, Hua Y, et al. Hepatitis C virus E2 envelope glycoprotein core structure. Science. 2013;342(6162):1090-4. https://doi. org/10.1126/science.1243876 PMID:24288331 PMCID:PMC3954638

20. Krey T, d'Alayer J, Kikuti CM, Saulnier A, Damier-Piolle L, Petitpas I, et al. The disulfide bonds in glycoprotein E2 of hepatitis C virus reveal the tertiary organization of the molecule. PLoS Pathog. 2010;6(2):e1000762.

https://doi.org/10.1371/journal.ppat.1000762 PMID:20174556 PMCID:PMC2824758

21. Lavillette D, Pécheur E-I, Donot P, Fresquet J, Molle J, Corbau R, et al. Characterization of fusion determinants points to the involvement of three discrete regions of both E1 and E2 glycoproteins in the membrane fusion process of hepatitis C virus. J Virol. 2007;81(16):8752-65. 
121. Development of Preventive Vaccines for...

https://doi.org/10.1128/JVI.02642-06 PMID: 17537855 PMCID:PMC1951381

22. Li Y, Modis Y. A novel membrane fusion protein family in Flaviviridae? Trends Microbiol. 2014;22(4):176-82. $\quad$ https://doi. $\underline{\text { org/10.1016/j.tim.2014.01.008 }}$ PMID:24569295 PMCID:PMC 3985287

23. Vieyres G, Thomas X, Descamps V, Duverlie G, Patel AH, Dubuisson J. Characterization of the envelope glycoproteins associated with infectious hepatitis $\mathrm{C}$ virus. J Virol. 2010;84(19):10159-68. $\quad$ https://doi.org/10.1128/ JVI.01180-10 PMID:20668082

24. Cocquerel L, Voisset C, Dubuisson J. Hepatitis $\mathrm{C}$ virus entry: potential receptors and their biological functions. J Gen Virol. 2006;87(5):1075-84. _ https://doi.org/10.1099/ vir.0.81646-0 PMID: 16603507

25. Naderi M, Gholipour N, Zolfaghari MR, Motalleb G. Hepatitis C virus and vaccine development. Int J Mol Cell Med. 2014;3(4):207-15. PMID:25635247 PMCID:PMC4293608

26. Steinhauer DA, Domingo E, Holland JJ. Lack of evidence for proofreading mechanisms associated with an RNA virus polymerase. Gene. 1992;122(2):281-8. https://doi.org/10.1016/03781119(92)90216-C

27. Simmonds P. Genetic diversity and evolution of hepatitis $\mathrm{C}$ virus-15 years on. Journal of General Virology. 2004;85(11):3173-88. https://doi. org/10.1099/vir.0.80401-0 PMID: $\underline{15483230}$

28. Simmonds P, Bukh J, Combet C, Deléage G, Enomoto N, Feinstone $\mathrm{S}$, et al. Consensus proposals for a unified system of nomenclature of hepatitis $\mathrm{C}$ virus genotypes. Hepatology. 2005;42(4):962-73. https://doi.org/10.1002/ hep.20819 PMID: 16149085

29. Cheng X-D, Xu H-F, Wei X-M, Zhou H-Z. Variation analysis of E1 and E2 in HCV subtypes. Archives of virology. 2015;160(10):247982. https://doi.org/10.1007/s00705-015-2533-9 PMID:26199129

30. Meunier J-C, Russell RS, Goossens V, Priem S, Walter H, Depla E, et al. Isolation and characterization of broadly neutralizing human monoclonal antibodies to the e 1 glycoprotein of hepa- titis C virus. J Virol. 2008;82(2):966-73. https:// doi.org/10.1128/JVI.01872-07 PMID: 17977972 PMCID:PMC2224608

31. Helle F, Dubuisson J. Hepatitis C virus entry into host cells. Cell Mol Life Sci. 2008;65(1):100-

12. $\quad$ https://doi.org/10.1007/s00018-007-7291-8 PMID: 17914604

32. Pileri P, Uematsu Y, Campagnoli S, Galli G, Falugi F, Petracca R, et al. Binding of hepatitis C virus to CD81. Science. 1998;282(5390):93841. https://doi.org/10.1126/science.282.5390.938 PMID: 9794763

33. Ploss A, Evans MJ, Gaysinskaya VA, Panis $\mathrm{M}$, You $\mathrm{H}$, de Jong $\mathrm{YP}$, et al. Human occludin is a hepatitis $\mathrm{C}$ virus entry factor required for infection of mouse cells. Nature. 2009;457(7231):882-6. https://doi. org/10.1038/nature07684_PMID:19182773 PMCID:PMC2762424

34. Scarselli E, Ansuini H, Cerino R, Roccasecca RM, Acali S, Filocamo G, et al. The human scavenger receptor class B type I is a novel candidate receptor for the hepatitis $\mathrm{C}$ virus. EMBO J. 2002;21(19):5017-25. https://doi. org/10.1093/emboj/cdf529 $\quad$ PMID: 12356718 PMCID:PMC 129051

35. Evans MJ, von Hahn T, Tscherne DM, Syder AJ, Panis M, Wölk B, et al. Claudin-1 is a hepatitis $\mathrm{C}$ virus co-receptor required for a late step in entry. Nature. 2007;446(7137):801-5. https:// doi.org/10.1038/nature05654 PMID:17325668

36. Keck Z-Y, De Beeck AO, Hadlock KG, Xia J, Li T-K, Dubuisson J, et al. Hepatitis C virus E2 has three immunogenic domains containing conformational epitopes with distinct properties and biological functions. J Virol. 2004;78(17):9224-32. https://doi.org/10.1128/

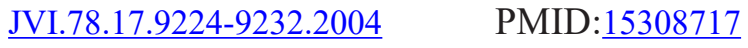
PMCID:PMC506923

37. Kachko A, Kochneva G, Sivolobova G, Grazhdantseva A, Lupan T, Zubkova I, et al. New neutralizing antibody epitopes in hepatitis $\mathrm{C}$ virus envelope glycoproteins are revealed by dissecting peptide recognition profiles. Vaccine. 2011;30(1):69-77. https://doi.org/10.1016/j.vaccine.2011.10.045 PMID: 22041300 
38. Grollo L, Torresi J, Drummer H, Zeng W, Williamson N, Jackson DC. Exploiting information inherent in binding sites of virus-specific antibodies: design of an $\mathrm{HCV}$ vaccine candidate cross-reactive with multiple genotypes. Antivir Ther. 2006;11(8):1005-14. PMID: 17302370

Zibert A, Schreier E, Roggendorf M. Antibodies in human sera specific to hypervariable region 1 of hepatitis $\mathrm{C}$ virus can block viral attachment. Virology. 1995;208(2):653-61. https://doi. org/10.1006/viro.1995.1196 PMID:7538251

40. Farci P, Shimoda A, Wong D, Cabezon T, De Gioannis D, Strazzera A, et al. Prevention of hepatitis $\mathrm{C}$ virus infection in chimpanzees by hyperimmune serum against the hypervariable region 1 of the envelope 2 protein. Proc Natl Acad Sci U S A. 1996;93(26):15394-9. https:// doi.org/10.1073/pnas.93.26.15394

41. Lechner S, Rispeter K, Meisel H, Kraas W, Jung $G$, Roggendorf $M$, et al. Antibodies directed to envelope proteins of hepatitis $\mathrm{C}$ virus outside of hypervariable region 1. Virology. 1998;243(2):313-21. https://doi.org/10.1006/ viro.1998.9069 PMID:9568031

42. Goffard A, Callens N, Bartosch B, Wychowski C, Cosset F-L, Montpellier C, et al. Role of N-linked glycans in the functions of hepatitis $\mathrm{C}$ virus envelope glycoproteins. J Virol. 2005;79(13):8400-9. https://doi.org/10.1128/ JVI.79.13.8400-8409.2005 PMID: 15956584 PMCID:PMC1143753

43. Wyatt R, Kwong PD, Desjardins E, Sweet RW, Robinson J, Hendrickson WA, et al. The antigenic structure of the HIV gp120 envelope glycoprotein. Nature. 1998;393(6686):705-11. https://doi.org/10.1038/31514 PMID: 9641684

44. Wei X, Decker JM, Wang S, Hui H, Kappes JC, Wu X, et al. Antibody neutralization and escape by HIV-1. Nature. 2003;422(6929):30712._https://doi.org/10.1038/nature01470 PMID: 12646921

45. Helle F, Vieyres G, Elkrief L, Popescu C-I, Wychowski C, Descamps V, et al. Role of N-linked glycans in the functions of hepatitis $\mathrm{C}$ virus envelope proteins incorporated into infectious virions. J Virol. 2010;84(22):11905-15. https:// doi.org/10.1128/JVI.01548-10 PMID:20844034

\section{PMCID:PMC2977866}

46. Edwards VC, Tarr AW, Urbanowicz RA, Ball JK. The role of neutralizing antibodies in hepatitis $\mathrm{C}$ virus infection. J Gen Virol. 2012;93(1):1-19. https://doi.org/10.1099/ vir.0.035956-0 PMID:22049091

47. Mondelli MU, Cerino A, Segagni L, Meola A, Cividini A, Silini E, et al. Hypervariable region 1 of hepatitis $C$ virus: immunological decoy or biologically relevant domain? Antiviral Res. 2001;52(2):153-9. https://doi.org/10.1016/S01663542(01)00180-2

48. Zibert A, Meisel H, Kraas W, Schulz A, Jung G, Roggendorf M. Early antibody response against hypervariable region 1 is associated with acute self-limiting infections of hepatitis C virus. Hepatology. 1997;25(5):1245-9. https:// doi.org/10.1002/hep.510250530 PMID:9141445

49. Shang D, Zhai W, Allain J-P. Broadly crossreactive, high-affinity antibody to hypervariable region 1 of the hepatitis $\mathrm{C}$ virus in rabbits. Virology. 1999;258(2):396-405. https://doi. org/10.1006/viro.1999.9730 PMID:10366577

50. Johansson DX, Voisset C, Tarr AW, Aung M, Ball JK, Dubuisson J, et al. Human combinatorial libraries yield rare antibodies that broadly neutralize hepatitis $\mathrm{C}$ virus. Proc Natl Acad Sci U S A. 2007;104(41):16269-74. https://doi. org/10.1073/pnas.0705522104_PMID: 17911260 PMCID:PMC2042196

51. Law M, Maruyama T, Lewis J, Giang E, Tarr AW, Stamataki Z, et al. Broadly neutralizing antibodies protect against hepatitis $C$ virus quasispecies challenge. Nat Med. 2008;14(1):25-7. https://doi.org/10.1038/nm1698 PMID: 18064037

52. Keck Z-Y, Sung VM, Perkins S, Rowe J, Paul $\mathrm{S}$, Liang TJ, et al. Human monoclonal antibody to hepatitis $\mathrm{C}$ virus $\mathrm{E} 1$ glycoprotein that blocks virus attachment and viral infectivity. J Virol. 2004;78(13):7257-63. https://doi.org/10.1128/ $\underline{\text { JVI.78.13.7257-7263.2004 PMID: } 15194801}$ PMCID:PMC421663

53. Allander T, Drakenberg K, Beyene A, Rosa $\mathrm{D}$, Abrignani $\mathrm{S}$, Houghton $\mathrm{M}$, et al. Recombinant human monoclonal antibodies against different conformational epitopes of the E2 envelope glycoprotein of 
hepatitis $\mathrm{C}$ virus that inhibit its interaction with CD81. J Gen Virol. 2000;81(10):24519. https://doi.org/10.1099/0022-1317-81-10-2451 PMID: 10993933

54. Mancini N, Diotti RA, Perotti M, Sautto G, Clementi N, Nitti G, et al. Hepatitis $C$ virus (HCV) infection may elicit neutralizing antibodies targeting epitopes conserved in all viral genotypes. PLoS One. 2009;4(12):e8254.

https://doi.org/10.1371/journal.pone.0008254 PMID: 20011511

55. Choo Q, Kuo G, Ralston R, Weiner A, Chien D, Van Nest G, et al. Vaccination of chimpanzees against infection by the hepatitis $\mathrm{C}$ virus. Proc Natl Acad Sci U S A. 1994;91(4):1294-8. https://doi.org/10.1073/pnas.91.4.1294

56. Frey SE, Houghton M, Coates S, Abrignani S, Chien D, Rosa D, et al. Safety and immunogenicity of HCV E1E2 vaccine adjuvanted with MF59 administered to healthy adults. Vaccine. 2010;28(38):6367-73. https://doi.org/10.1016/j. vaccine.2010.06.084 PMID:20619382 PMCID:PMC2923449

57. Ray R, Meyer K, Banerjee A, Basu A, Coates S, Abrignani $\mathrm{S}$, et al. Characterization of antibodies induced by vaccination with hepatitis $\mathrm{C}$ virus envelope glycoproteins. J Infect Dis. 2010;202(6):862-6. https:// doi.org/10.1086/655902 PMID:20677942 PMCID:PMC2931414

58. Law J, Chen C, Wong J, Hockman D, Santer $\mathrm{DM}$, Frey SE, et al. A hepatitis C virus (HCV) vaccine comprising envelope glycoproteins $\mathrm{gpE} 1 / \mathrm{gpE} 2$ derived from a single isolate elicits broad cross-genotype neutralizing antibodies in humans. PLoS One. 2013;8(3):e59776. https://doi.org/10.1371/journal.pone.0059776 PMID:23527266 PMCID:PMC3602185

59. Owsianka AM, Timms JM, Tarr AW, Brown RJ, Hickling TP, Szwejk A, et al. Identification of conserved residues in the E2 envelope glycoprotein of the hepatitis $\mathrm{C}$ virus that are critical for CD81 binding. J Virol. 2006;80(17):8695704. https://doi.org/10.1128/JVI.00271-06 PMID:16912317 PMCID:PMC1563869

60. Boo I, Douam F, Lavillette D, Poumbourios P, Drummer HE. Distinct roles in folding, CD81 receptor binding and viral entry for conserved histidine residues of hepatitis $\mathrm{C}$ virus glycoprotein E1 and E2. Biochem J. 2012;443(1):8594. https://doi.org/10.1042/BJ20110868 PMID: 22240035

61. Drummer HE, Boo I, Maerz AL, Poumbourios P. A conserved Gly436-Trp-Leu-Ala-Gly-LeuPhe-Tyr motif in hepatitis $C$ virus glycoprotein $\mathrm{E} 2$ is a determinant of CD81 binding and viral entry. J Virol. 2006;80(16):7844-53. https:// doi.org/10.1128/JVI.00029-06 PMID:16873241 PMCID:PMC1563787

62. Roccasecca R, Ansuini H, Vitelli A, Meola A, Scarselli E, Acali S, et al. Binding of the hepatitis $\mathrm{C}$ virus $\mathrm{E} 2$ glycoprotein to $\mathrm{CD} 81$ is strain specific and is modulated by a complex interplay between hypervariable regions 1 and 2. J Virol. 2003;77(3):1856-67. https://doi.org/10.1128/ $\underline{\text { JVI.77.3.1856-1867.2003 }}$ PMID: $\underline{12525620}$ PMCID:PMC140892

63. Hsu M, Zhang J, Flint M, Logvinoff C, ChengMayer C, Rice CM, et al. Hepatitis C virus glycoproteins mediate $\mathrm{pH}$-dependent cell entry of pseudotyped retroviral particles. Proc Natl Acad Sci U S A. 2003;100(12):7271-6. https://doi. org/10.1073/pnas.0832180100 PMID: 12761383 PMCID:PMC165865

64. Sabo MC, Luca VC, Prentoe J, Hopcraft SE, Blight KJ, Yi M, et al. Neutralizing monoclonal antibodies against hepatitis $\mathrm{C}$ virus E2 protein bind discontinuous epitopes and inhibit infection at a postattachment step. J Virol. 2011;85(14):7005-19. https://doi. org/10.1128/JVI.00586-11 PMID:21543495 PMCID:PMC3126585

65. Higginbottom A, Quinn ER, Kuo C-C, Flint M, Wilson LH, Bianchi E, et al. Identification of amino acid residues in CD81 critical for interaction with hepatitis $\mathrm{C}$ virus envelope glycoprotein E2. J Virol. 2000;74(8):3642-9. https://doi.org/10.1128/JVI.74.8.3642-3649.2000 PMID: $10729140 \quad$ PMCID:PMC111874

66. Broering TJ, Garrity KA, Boatright NK, Sloan SE, Sandor F, Thomas WD, et al. Identification and characterization of broadly neutralizing human monoclonal antibodies directed against the E2 envelope glycoprotein of hepatitis C 
virus. J Virol. 2009;83(23):12473-82. https:// doi.org/10.1128/JVI.01138-09 PMID:19759151 PMCID:PMC2786766

67. Tarr AW, Owsianka AM, Timms JM, McClure CP, Brown RJ, Hickling TP, et al. Characterization of the hepatitis $C$ virus $\mathrm{E} 2$ epitope defined by the broadly neutralizing monoclonal antibody AP33. Hepatology. 2006;43(3):592-601. https://doi.org/10.1002/hep.21088 PMID:16496330

68. Owsianka A, Tarr AW, Juttla VS, Lavillette D, Bartosch B, Cosset F-L, et al. Monoclonal antibody AP33 defines a broadly neutralizing epitope on the hepatitis C virus E2 envelope glycoprotein. J Virol. 2005;79(17):11095-104. https://doi.org/10.1128/JVI.79.17.11095-11104.2005 PMID:16103160 PMCID:PMC1193588

69. Owsianka A, Clayton RF, Loomis-Price LD, McKeating JA, Patel AH. Functional analysis of hepatitis C virus E2 glycoproteins and virus-like particles reveals structural dissimilarities between different forms of E2. J Gen Virol. 2001;82(8):1877-83. https://doi.org/10.1099/0022-1317-82-8-1877 PMID: 11457993

70. Cocquerel L, Meunier J-C, Pillez A, Wychowski C, Dubuisson J. A retention signal necessary and sufficient for endoplasmic reticulum localization maps to the transmembrane domain of hepatitis C virus glycoprotein E2. J Virol. 1998;72(3):2183-91. PMID: 9499075 PMCID:PMC109514
71. Perotti M, Mancini N, Diotti RA, Tarr AW, Ball JK, Owsianka A, et al. Identification of a broadly cross-reacting and neutralizing human monoclonal antibody directed against the hepatitis C virus E2 protein. J Virol. 2008;82(2):104752. https://doi.org/10.1128/JVI.01986-07 PMID:17989176 PMCID:PMC2224572

72. Hadlock KG, Lanford RE, Perkins S, Rowe J, Yang Q, Levy S, et al. Human monoclonal antibodies that inhibit binding of hepatitis $\mathrm{C}$ virus $\mathrm{E} 2$ protein to $\mathrm{CD} 81$ and recognize conserved conformational epitopes. J Virol. 2000;74(22):10407-16. https://doi.org/10.1128/ JVI.74.22.10407-10416.2000 PMID: 11044085 PMCID:PMC 110915

73. Owsianka AM, Tarr AW, Keck Z-Y, Li T-K, Witteveldt J, Adair R, et al. Broadly neutralizing human monoclonal antibodies to the hepatitis $\mathrm{C}$ virus $\mathrm{E} 2$ glycoprotein. J Gen Virol. 2008;89(3):653-9. https://doi. org/10.1099/vir.0.83386-0 PMID: 18272755 PMCID:PMC2885755

74. Clayton RF, Owsianka A, Aitken J, Graham S, Bhella D, Patel AH. Analysis of antigenicity and topology of E2 glycoprotein present on recombinant hepatitis $\mathrm{C}$ virus-like particles. J Virol. 2002;76(15):7672-82. https://doi.org/10.1128/ JVI.76.15.7672-7682.2002 PMID: 12097581 PMCID:PMC136371 